\title{
Assessment of employment potential for fisheries professionals in India
}

\author{
RASHMI AGRAWAL ${ }^{1}$, RAMA RAO DARAPUNENI ${ }^{2}$, BANDA V. L. N. RAO ${ }^{3}$, S. K. NANDA ${ }^{2}$ \\ AND SANCHITA BHATTACHARYA ${ }^{1}$ \\ ${ }^{1}$ Institute of Applied Manpower Research, Narela, New Delhi-110 040, India \\ ${ }^{2}$ National Academy of Agricultural Research Management, Hyderabad - 500 030, Telangana, India \\ ${ }^{3}$ Indian Statistical Service, Planning Commission, New Delhi, 500 001, India \\ e-mail: ramarao@naarm.ernet.in
}

\begin{abstract}
This paper reports the results of an assessment of human capital requirement in fisheries sector in India using a mixed methodology. Quantitative and qualitative data were collected through a nationwide survey covering employers and various stakeholders as well as focus group discussions. The results indicated that the estimated number of 5,140 fisheries science graduates in 2010, at current levels of output, would reach 6,700 by 2020, against the estimated demand of 28,400 in that year. Aquaculture, fish farming and processing are the major employment subsectors for fisheries professionals. Experts pointed to the need for more public investment in fisheries research and education to increase quality of human resources. The study indicates emerging demand for technicians and skilled workers to cater to the needs at lower levels in almost all subsectors of fisheries.
\end{abstract}

Keywords: Employment, Fisheries professional, Forecasting, Manpower, Supply-demand

\section{Introduction}

Fisheries sector plays an important role in the national economy with a share of $1 \%$ in the total GDP and $5.4 \%$ in the agricultural GDP in 2009-10. India is the sixth largest producer of fish and second largest producer of inland fish in the world. The fisheries sector provides employment to about 14 million people in fishing and related activities directly or indirectly. For each person employed in capture fisheries and aquaculture production, about three jobs are created in the allied activities including post-harvest (GOI, 2011a). Out of the total estimated potential of 12.9 million $t$ of fish production, the actual production in 2010-11 was about 8.3 million t; 3.22 million $t$ from marine sector and 5.07 million $\mathrm{t}$ from inland sector (DAHD, 2012). During the past five decades, fish production has increased at an annual rate of 4.1\%. During 2000-01 to 2007-08, the overall growth was however, lower at only $3 \%$ per annum $(0.4 \%$ in the marine sector and $5.2 \%$ in the inland sector).

A number of researchers reported manpower requirements in fisheries sector, their estimates widely varying from a few thousand to hundreds of thousands of persons of varying training, education and skill levels (Chidambaram, 1985; James, 1987; Thakur et al., 1997; Kohli, 1998; Ayyappan and Biradar, 2000). A recent study by Central Institute of Fisheries Education (CIFE) makes a more systematic effort to project requirement of fisheries graduates by 2020 and estimates need for 10,457 against a supply of 4,570 (Munil Sukham, 2010). The XII plan Working Group report on fisheries gives high priority to manpower development for the envisaged technology led growth in the sector (GOI, 2011a). Considering the wide range in various manpower assessments made in the past, the present paper is an attempt to systematically investigate the requirement and availability of the trained manpower in the sector.

\section{Materials and methods}

Assessment of the future human resource situation involves forecasting level of demand for various skills that is likely to arise, estimating the likely supply of such skills from the existing channels and then matching the two to assess the likely future shortages or surpluses of various skills. While the supply arises from the outturn from educational institution (and on-the-job training), the demand consists of two components, arising out of the growth of the economy and the other (replacement demand) due to attritions of human resources for various reasons such as retirements, deaths and migration.

A number of sectors of the economy employ personnel qualified in fisheries sciences and technology, such as the government departments, private sector including self employment, academic and research institutions, processing units, financial institutions, as well as other units of trade and civil society organisations. 
A reasonable demand forecast has to take into account the existing situation in different sub-sectors of employment, the past trend and the emerging future.

A variety of demand forecasting techniques have been employed in different countries such as employer survey methods, norm-based methods, time-series, regression and other economic and Parnes's manpower requirements approach (Parnes, 1962). The choice of methods is often dictated by the practical constraints of availability of data and their quality.

Notwithstanding the great strides made by India in the organisation of its statistical system, relevant data is not available in requisite detail or with sufficient frequency that enables establishment of employment trends for different occupations in different sectors as is done in developed countries. In the present study, therefore, a mix of quantitative and qualitative methodologies has been followed. The quantitative data collected through structured questionnaires has been collated with qualitative inputs collected through Focus Group Discussions. Considering the plurality in data availability, a number of forecast methods were employed as per the data availability in the associated sub-sectors. The quantitative methods employed include normative methods for some sub-sectors, adaptation of Parnes' approach to some, and analysis of trends to yet others.

Normative approach applied, followed the norms developed by CIFE for professional and technical personnel for sub-sectors of employment in fisheries. In some other sectors of employment, such as processing industries, the essentials of Parnes' approach formed the basis. The Parnes's approach in its original form is used for estimation of human resource demand for all sectors of the economy, by first forecasting total employment in different sectors and then breaking down the total employment forecasts into occupational forecasts first and then educational forecasts. In the present study, the occupational and educational forecasts are obtained by modifying the present patterns and some others by trend analysis. This involved the forecasting of total employment in the sub-sector first and then breaking it down by education, applying patterns observed currently and modified for future, whereever possible, in consultation with experts.

Once the total employment was thus projected, estimates of employment of various types of fisheries graduates were obtained by applying the pattern of absorption of fisheries manpower of various disciplines in different sub-sectors of the economy obtained through an extensive survey of establishments conducted during 2009-10 all over the country. This establishment survey was conducted through a two-stage stratified sampling, the districts in each state being the first stage units and the establishments in the district being the second stage units. A total of 2,084 establishments were covered. The projections are made with 2010 as base year and 2010 to 2020 as the forecast horizon. The primary data required for assessing the prevailing employment patterns have been collected in fisheries sector from 111 establishments from 103 districts covering the industrial units, government departments as well as self employment units. Besides all the educational institutions under ICAR, alumni (127) and other employees (individual experts) were covered which followed focus group discussions (FGDs) with various stakeholders in fisheries sector. Secondary data were collected from published reports, official publications and web sites of related organisations.

Trend methods were used based on the existing situations, government policies, future staff expansion, and future investments or development visions.

The rigor of methodology ensures that the error would be small. However, major source of error emanates from the changes in estimation of variables like economic factors such as growth rate. In fact, the study estimated future demand at two extreme values of growth, one based on business as usual and the other based on high growth contemplated in the plan documents. The average appeared more reasonable to explain the demand in the current decade. Considering this, the average of the two growth scenarios was used in demand estimation. The error on this account would be about $10 \%$ estimations in certain functional areas. Notwithstanding the magnitude of error, the study provides scope for demand in various functional areas that has implications on quality of manpower required at different levels of education. This is important for educational planning.

The supply projections were obtained in two steps. First, the stock of agricultural graduates in 2009-10 was estimated through cumulating the annual outturns of graduates from the agricultural universities over the past 38 years (the working span of graduates; for post-graduates this was taken as 36 years) and discounting for annual attrition at 3\% per annum. This estimate was then carried forward over the projection horizon with the annual outturn held constant at the level of institutional outturn in 2009-10. The survey of agricultural universities and colleges was conducted on census basis. The annual outturns obtained through a comprehensive survey of all agricultural universities also generated considerable qualitative data on agricultural education.

The employment distribution by different education levels were obtained from the establishment survey results. 
Assuming that the present composition of education levels of the workforce would continue in the future, the total stock forecast was decomposed for assessing educational level-wise demand. The annual flow requirement was calculated considering the demand for new jobs arising from the sub-sector growth, flow to higher education and the replacement to compensate for the attrition. An attrition rate of $3 \%$ was estimated to take care of replacement due to retirement, migration and death.

\section{Results and discussion}

\section{Supply estimation}

Fisheries education is offered in the country through 26 colleges from 20 State Agricultural/Veterinary Universities (AUs), Central Agricultural University, Central Institute of Fisheries Nautical and Engineering Training (CIFNET), Kochi; Central Institute of Fisheries Education (CIFE), Mumbai and Indian Institute of Technology (IIT), Kharagpur. Undergraduate (UG) courses are offered in 24 colleges, postgraduate $(\mathrm{PG})$ courses in 18 and doctorate course (Ph.D) in nine colleges/institutes. In addition, few colleges/departments in general universities offer postgraduate courses in related disciplines like marine biology and such courses are not included in the present study.

The current intake capacity in all the graduate courses (UG, PG and Ph. D) is about 1,000. Average intake and outturn of students at various levels during 2008-10 is given in Table1. About 420 students are produced annually, against an intake of 700 students. In addition, diploma/ vocational education are provided by CIFNET, Kochi and Sri Venkateswara Veterinary University (SVVU), Tirupati with a total intake of about 200 students. Besides this, some other institutions in general universities offering higher level of fisheries related education have not been included in supply estimation.

Stock estimation from supply: There is no direct source of data available for the number of active fisheries science graduates in the country. Thus, stock in the base year for the study, i.e., 2010, was estimated indirectly by cumulating the outturn of fisheries graduates over several years obtained from different sources (CSIR, 1993; Rama Rao and Muralidhar, 1994; IAMR, 2001; DST, 2010; IASRI, 2011; Rama Rao et al., 2011). The stock of graduates in fisheries sciences estimated from outturn data since 1973 assuming that an average fisheries graduate completes the course at the age of 23 and remains in service till he reaches 60; it is necessary to accumulate the outturns for 37 years from 1973 to reach the stock in 2010 and adjusted for attrition (at 3\% per annum), is about 5,144 in 2010 .

The outturns do not directly relate to the intakes shown, as the outturn in a year arises out of intake a few years earlier ( 4 years in the case of graduates, 2 years in the case of post-graduates and 3 years or more in the case of $\mathrm{Ph}$. Ds). Dropouts in agricultural education in general occur as quite a few persons joining these courses opt out to join medical or other professional streams later.

\section{Demand estimation}

Almost all sub-sectors employ number of persons for lower level jobs below fisheries graduate level. Such persons are often termed by many sub-sectors as technicians or skilled and semi-skilled staff. This category includes diploma holders, vocationally trained and other educated persons trained on the job. The demand assessment has been made separately for each of the nine fisheries sub-sectors and the results are summarised below.

\section{Fish processing}

During XI five year plan, fish processing grew at $4 \%$ per annum against plan target of $6 \%$ per annum. The total fish production has been projected to be about 12.8 million $t$ in 2020 , using the average growth rate of 5\% per annum. The vision 2015 document of Ministry of Food Processing industries envisaged growth in fish processing sector by $15 \%$ of the production by 2010 and $20 \%$ by 2015 . With the processing sector assumed to grow as envisaged and to continue till 2020, the volume of fish processing would grow to 3.2 million t. As per the Annual Surveys of Industries (ASI) data, the number of fish processing units in 2007-08 was 327, processing about $13 \%$ of production, i.e., 9,27,000 t (CSO, 2011). Average quantity of processing and number employed per unit being $2,835 \mathrm{t}$ and 120 respectively. Thus, the targeted amount of fish processing in 2020 is expected to engage a total of about 0.14 million persons. Establishment survey indicated that about $12.7 \%$ of total employed in these units have fisheries related education (Primary survey of establishment by authors). The projections for stock of fisheries graduates of about 4,040 in 2010 would increase to 11,240 by 2020 . The corresponding estimate for technical persons is 1,066 in 2010 and 2,965 in 2020.

Table 1. Average intake and outturn of students in fisheries sciences during 2008-10

\begin{tabular}{|c|c|c|c|c|c|c|c|c|}
\hline & \multicolumn{2}{|c|}{ Undergraduate (UG) } & \multicolumn{2}{|c|}{ Postgraduate (PG) } & \multicolumn{2}{|c|}{ Ph. D } & \multicolumn{2}{|c|}{ Total admitted } \\
\hline & Intake & Outturn & Intake & Outturn & Intake & Outturn & Intake & Outturn \\
\hline Number of students & 465 & 252 & 168 & 119 & 22 & 30 & 679 & 416 \\
\hline
\end{tabular}




\section{Aquaculture:}

Aquaculture is the most promising sub-sector with a potential area of 1.2 to $1.4 \mathrm{~m}$ ha of brackishwater resources, of which about $10 \%$ is actively used. In 2011 , about 20,286 aquaculture units registered with Coastal Aquaculture Authority of India, which included 104 large units, 2,948 medium units and the rest small units (CAA, 2011). Separate norms are recommended for inland and brackishwater aquaculture farms (CIFE, 2000). Considering large variety of fish farms, the following norms are used for estimation of manpower: At least one graduate and eight technicians for a farm of 10 ha or more, one graduate and about six technicians for medium farm of size 2-10 ha and about four technicians for small farms below 2 ha. It is assumed that at least two-thirds of the units have undergraduates now and by 2020 all such units will employ at least one graduate. On this basis, the requirement of aquaculture trained persons in 2010 was estimated at about 2,100 graduates and 91,000 technicians. Inland water fish production has shown an annual growth rate of $5.2 \%$ during $2000-01$ to $2007-08$ against the plan projection of $8 \%$. An average $7 \%$ growth is taken for estimation of stock up to 2020. The projected stock demand would be 4,130 graduates and about 1,78,920 technicians by 2020 .

\section{Fish seed hatcheries}

In 2010 , fish seed production was about 25 billion fry. The hatcheries have recorded a growth of $5 \%$ per annum between 1997-98 and 2007-08. With about 150 hatcheries in operation, the average production per unit works out to be about 160 million fry. As per CIFE norms, a fish seed hatchery of capacity 10 to 50 million fry would need 4-8 graduates and 12-24 technicians. In addition, there are about 1,600 circular Chinese hatcheries producing about 50 million fry per annum and 1,200 hapa hatcheries with an average production of four million fry each. These small units may not employ graduates. However, a hatchery with 2-5 million fry per year capacity would require six technicians, while a hatchery of 10-50 million fry of annual capacity would require 16 technicians. It is assumed that the number of hatcheries, of all types, would grow by $5 \%$ per annum. The stock requirements (estimated on this basis) of 1,330 graduates in 2010 would grow to 2,170 in 2020. The corresponding requirement for technical persons is expected to increase from 32,800 in 2010 to 53,400 in 2020.

\section{Fish feed industry}

A normative approach has been used to forecast demand in this sub-sector also. There are about 40 fish feed industrial units with an installed capacity of 1,50,000 t. About 20 major units employ about 100 fisheries graduates and they would require an additional 250 by 2020 . Assuming that the remaining 20 medium size units require four fisheries graduates each, the requirement of fisheries graduates in feed industry would grow from 180 in 2010 to 500 in 2020.

\section{Deep sea fishing}

Deep sea fishing needs more landing centers and long line trawlers with adequate freezing facilities. Mechanisation of boats and increased storage capacity have enhanced the productivity 2 to 3 times. About 60 deep sea vessels were in operation in 2010 (MPEDA, 2011). Although the number of deep sea vessels with on-board facilities is still small, the number of deep sea trawlers has been steadily increasing. Experts opine that the number may grow to 200 by 2020 . The technologies and skills for long line trawlers and fishing in deep sea would generate employment for fisheries professionals. Vessels over $35 \mathrm{~m}$ long would require on average three graduates and 15 deckhands (technicians). On this basis, this sub-sector needed about 180 fisheries graduates in 2010 , which is projected to increase to 600 by 2020 . The corresponding requirement for deckhands would increase from 900 in 2010 to 3,000 by 2020 .

\section{Development and extension}

Development of fisheries is primarily the responsibility of State Governments. Besides, Krishi Vigyan Kendras (KVKs), the National Fisheries Development Board (NFDB) and Marine Products Export Development Agency (MPEDA play prominent role in extension work. In 2010, State Departments of Fisheries had a total sanctioned strength of 4,846 positions, of which 3,762 were filled and 1,084 were vacant (Munil Sukham, 2010). The departments have projected an additional need for 2,838 posts by 2020 taking the total to 7,684 by that year. Considering the recent trends in state government employment, it is unlikely that there would be expansion of this size. What is more reasonable to expect is that the current vacancies would be filled and a few more created by then taking the total employment to 5,000 .

MPEDA had 49 fisheries graduates in 2010. The number is projected to grow to 79 by 2020 . KVKs, which have a total employment of 87 fisheries graduates in 2010, would need 400 by 2020 . The National Fisheries Development Board has about 15 executive level professionals in fisheries (NFDB, 2011). About 450 Fish Farmers' Development Agencies have a collective strength of about 12,000 fisheries related skilled persons and professionals. In all these public funded organisations, the estimates for 2020 have been made assuming filling up of $80 \%$ of the existing vacancies (sourced from CIFE, Mumbai). The number of fisheries graduates required for extension work is projected to grow from 3,820 in 2010 to 6,200 by 2020 . 


\section{Research and academic}

As of April 2010, the eight fisheries Institutions in ICAR had a sanctioned scientific strength of 679 (35\% vacant), which includes 397 scientists in fisheries discipline (Fish and Fisheries Science 360, Fish Pathology and Fish Processing Technology 36). Thus, with 35\% vacancies, ICAR had 270 fisheries scientists in position in 2010. In 2010, SAUs had sanctioned strength of 682 personnel in fisheries disciplines, with 403 in position. Apart from ICAR and SAUs, scope for research in fisheries is limited. Fisheries Survey of India, which had a sanctioned strength of 67 has 20 vacancies and projected their additional needs as 18 to take the total strength to 85 by 2020 . Considering these factors, manpower in fisheries research and education has been projected to grow at $2 \%$ per annum only through filling up of the vacant posts. The total number of fisheries graduates in research and academic sector added to 720 in 2010 and the number of graduates needed in this sub-sector of employment is estimated to be 1200 by 2020 .

\section{Financial institutions}

In 2008, nationalised banks in India had about 8.38 lakhs employees, out of which $40 \%$ were officers. The primary establishment survey indicated that about $3.9 \%$ of the total employment (or $10 \%$ of the officers) in banks comprised graduates in agriculture and allied sciences. Employment of officers in public sector banks has been projected to grow at $2.5 \%$ per annum on the basis of the trend in recent years. On this basis, the number of graduates in agriculture and allied sciences has been projected to grow from 35,100 in 2010 to 45,000 by 2020 . Assuming that fisheries graduates among them are in the same ratio as they are in the annual outturn of graduates in all agricultural sciences, the total number of fisheries graduates in banks in 2010 was taken as about 300. In addition, another 200 fisheries graduates were in financial institutions like NABARD and insurance companies making a total of 500 in 2010 . On a conservative growth rate of $2.5 \%$ per annum, the same as that observed in the overall employment in banks in recent years, the number of fisheries graduates was projected to rise from 500 in 2010 to 750 by 2020 .

\section{Others}

Some fisheries graduates find self-employment in other sectors, though to a limited extent. For example, between April 2002 and September 2010, a total of 178 agri-clinics were sanctioned specifically for fisheries related activities (MANAGE, 2011). Again, focus group discussions revealed that a good number of fisheries science graduates find employment overseas, particularly in the east African and Gulf countries. The demand from all such sectors, such as civil services, fishing equipment industry, NGOs, agri-clinics and other self-employment, and global demand was taken as $5 \%$ of the total demand assessed for the various sub-sectors.

\section{Gross stock demand}

Subsector-wise estimates of the stock of fisheries human resources in 2010 and projections for 2020 are summarised in Table 2. The stock of such graduates required would increase from 13,489 in 2010 to 28,097 in 2020. The number of technicians required would increase from $1,32,186$ in 2010 to $2,51,146$ in 2020. In general, the demand for technicians is nearly ten times that of graduates.

\section{Demand supply gap in stock}

In 2010, the actual stock of graduates estimated by cumulating annual outturns adjusted for attrition was 5,144 . During 2006-10, the supply had grown at $2.6 \%$ per annum. At this growth rate, the supply would reach 6,705 by 2020 . As the estimated demand from various sub-sectors would be 28,097 in 2020 , the demand-supply gap would be 21,392 (i.e. $76 \%$ of the demand) in that year.

\section{Annual flow demand}

The above stock projections have been converted to annual flows required out of the educational system, taking into account: (a) the growth from year to year, (b) replacement needs calculated at the rate of 3\% and (c) the needs of higher education. Break-up by level of qualification is made on the basis of their proportions in the sub-sectors obtained from the establishment survey.

The annual supply in 2010 and the projected flow demand in 2020 for fisheries science graduates is shown in Fig. 1. The projections suggest that by 2020, the annual outturn required from the fisheries science education system should be about 2,610 graduates. The current annual supply of about 420 graduates per year is too

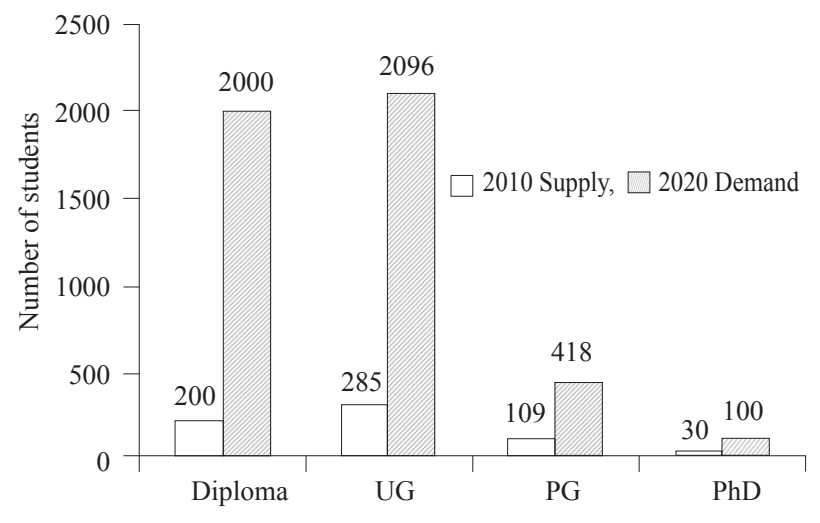

Fig. 1. Supply of fisheries professionals in 2010 and outturn required in 2020 in fisheries sector 
less compared to the requirement of 2,600 by 2020 . The net addition to annual outturn required is about 2,190 graduates.

The industry needs trained graduates but can't afford to meet the graduates' expectations in terms of wages and working environment. For this reason, industry prefers technicians with lower level education such as general science graduates or matriculates with on job training. The views of the experts during focus group discussions suggested that professionally trained diploma holders should replace technicians now in place. There are not many such formally trained diploma holders in the country.

Based on expert judgment about human resources in government, banks, research and academic sectors, the division of manpower requirements between inland and marine sub-sectors is in the ratio of 60:40. The annual flow projections for the marine and inland sub-sectors, so derived are given in Table 3. During 2010 to 2020, the annual flow of graduates required would increase from 956 to 1,610 in marine and from 680 to 1,004 in inland sub-sectors.

Thus, by 2020, the demand for graduates is likely to be more in marine than in inland sub-sector, whereas the demand for technicians will be more in inland as compared to marine sub-sector.

Education in fisheries sciences during 2000-2010 recorded a growth of $4 \%$ per annum, which is the lowest within all branches of agricultural sciences. In fact, even this modest rate of growth was the result of higher growth at PG and Ph. D levels. Undergraduate education in fisheries sciences grew at $2 \%$ per annum. As future growth in employment is envisaged more in private sector, there is need for expansion of UG education by five-fold by 2020 . This could be achieved partly by better utilisation of existing capacities and partly by establishing new colleges, especially in agricultural universities not offering fisheries courses at present. Sub-sector demand for fisheries graduates shows that academic and research sectors need more PG/Ph.Ds, whereas all other subsectors need more of diploma and undergraduate students. Demand from academic and research sectors is high for PG and Ph.Ds from current supply of 140 to a need of
520 by 2020 . In view of the large number of vacancies available currently in these two knowledge sectors, there is a need to increase investments in fisheries research and education so as to increase research opportunities and quality human resource production.

With general buoyancy in the economy, the fisheries sector is likely to show an impressive growth of $5 \%$ per annum in the next decade, albeit a bit lower than that projected by the planning commission. However, the demand for professional manpower in the sector may not grow at the same rate as the sector output growth. The present structure of aquaculture industry may not continue in the existing shape. For example, if the future production takes place in the smaller farms, such farms may not employ any fisheries graduate. Moreover, substitutability of skills by other graduates may also depress the demand. The industry feels that the expectations of the professional graduates are too high for them to be able to afford. Thus, most employers prefer technicians who can be paid less than trained professionals. Considering such imponderables, the actual demand may be somewhat lower. Nevertheless, such suppressed demand would also require much more than current supply of trained professionals. Hence, there is need for increasing supply at all levels, beginning with diploma level on priority.

Apart from quantity, a major issue is the quality of professionals produced. Quality of graduates is not uniform across colleges. With nearly faculty vacancies to the tune of $40 \%$ in many fisheries colleges, lack of faculty is affecting the quality of graduates. Fisheries education is not viable in the private sector in commercial perspective. As private sector is unlikely to enter into fisheries education, public sector support is inevitable.

New job opportunities are emerging for fisheries professionals. With expansion of super-markets, even in smaller towns, demand for professionals would grow for managing various functions on the supply chain. A number of students passing out from fisheries colleges are interested in self-employment by venturing in to fish seed production, aquaculture, ornamental fish trade and fish feed manufacture.

Table 3. Requirement of human resources in marine fisheries and inland sub-sectors

\begin{tabular}{|c|c|c|c|c|c|c|}
\hline \multirow[t]{2}{*}{ Sector } & \multirow[t]{2}{*}{ Year } & \multicolumn{5}{|c|}{ Number required annually during 2010 to 2020} \\
\hline & & Diploma & Undergraduates (UG) & Postgraduates (PG) & Ph.D. & All graduates \\
\hline \multirow[t]{2}{*}{ Marine } & 2010 & 684 & 769 & 151 & 37 & 956 \\
\hline & 2020 & 1088 & 1304 & 249 & 57 & 1610 \\
\hline \multirow[t]{2}{*}{ Inland } & 2010 & 12095 & 530 & 118 & 32 & 680 \\
\hline & 2020 & 21605 & 792 & 169 & 42 & 1004 \\
\hline
\end{tabular}


Many fisheries related operations like boat management and fish processing are employing non-fisheries graduates. There is demand for human resources at low cost. The sector would be better served if diploma students are available for such positions. On the whole, this sector has a large scope to replace about 2,50,000 unqualified persons now working as technicians. Such technicians generally come from short training courses of a few months duration or trained through apprenticeship on the job. A more detailed analysis is needed to have a better picture of the distribution of this requirement at various levels like diploma, ITI and other certificate courses. Considering experience in other sectors, these three categories may be in the ratio of $1: 3: 6$. In such scenario, the country needs about 25,000 diploma holders by 2020. This translates to a supply of about 2,000 diploma holders per annum, and being 2 to 3 times the supply of undergraduates gives a desirable ratio.

CIFNET is providing vocational education programs in fisheries under the Ministry of Labour and Employment's vocational training scheme (CIFNET, 2012). Government of India has plans to establish large number of new vocational schools and skill development centres across the country (Luv Jasuja and Prashant Kashyap, 2008; GOI, 2011b). Such new schemes, in addition to existing programmes can be sourced for meeting this requirement. There is need to synergise schemes under different government departments to develop para-professionals (technically qualified personnel) in fisheries sector, that provide employment opportunities especially for the rural youths, thereby augmenting incomes of the rural households.

The working group report on fisheries for the XII plan stresses the importance of need-based programmes for human resources development (GOI, 2011a). It is expected that the human resource development programmes will cover a wide range of stakeholders (fishermen to extension personnel and sector managers) to ensure that the skills and capacities are built at all levels to ensure sustainable development of the sectors. Although, the present study and other ICAR initiatives address skill needs for graduates and above, a more in-depth analysis of the sub-sector requirements would provide a more rational picture on human resource development needs at all levels.

Sectoral approach to manpower assessment like the present exercise no doubt provides an indication of future demand by skill level and possible shortages (Castley,1996). However, to examine the structural balance in the stock and flow of skills by level and qualitative requirements in different sub-sectors, micro-studies are required. The present study points the need to undertake more focused sub-sector studies of key occupations by level of education and training.
The fisheries science graduates stock is estimated to grow from 13,489 in 2010 to 28,097 in 2020. Current annual supply is about 200 diploma and 424 graduates. Education level-wise, additional requirement by 2020 is for 2,000 diploma holders, 1,810 UGs, 310 PGs and $70 \mathrm{Ph} . \mathrm{Ds}$. In view of large vacancies in the public funded knowledge sectors in $\mathrm{R} \& \mathrm{D}$, there is a need to increase investments for improving fisheries research and education and thereby to increase quality human resource production. Indian fisheries sector would be better served by developing rural youth as para-professionals (technicians).

\section{Acknowledgements}

Authors acknowledge the financial support received for conducting the study from National Agricultural Innovation Project of ICAR, New Delhi.

\section{References}

Ayyappan, S. and Biradar, R. S. 2000. Manpower requirements and human resource development in fisheries sector. Report of the brainstorming session, Education Division of Indian Council of Agricultural Research, New Delhi and Central Institute of Fisheries Education, 20-21 October 2000, ICAR-Central Institute of Fisheries Education, Mumbai, India.

CAA 2011. Annual report 2010-11. Coastal Aquaculture Authority, Ministry of Agriculture, Government of India, Chennai. http://www.caa.gov.in/ (Accessed 15 December, 2011).

Castley, R. J. Q. 1996. The sectoral approach to the assessment of skill needs and training requirements. Int. J. Manpower, 17(1): 56-68.

CIFE 2000. Report of the Brainstorming session on Human Resorces requirements and HRD in Fisheries Science. Central Institute of Fisherires Education, Mumbai, India.

CIFNET 2012. Central Institute of Fisheries Nautical and Engineering Training, Kochi. http://www.cifnet.nic.in (Accessed 29 November, 2012).

Chidambaram, K. 1985. Manpower planning: An assessment for the next decade. In: Kulkarni, G. R. and Srivatsava, U. K (Eds.), A systems framework of the marine foods industry in India. Concept Publishing Company, New Delhi, p. 333-374.

CSIR 1993. Out turn of scientific and technical manpower in India. HRD Group, CSIR, New Delhi, vol. 1-4.

CSO 2011. Annual survey of industries. Central Statistical Organisation, New Delhi.

DAHD 2012. Basic animal husbandry statistics. Department of Animal Husbandry, Govt. of India, New Delhi. 
DST 2010. Research and development statistics 2007-08. Department of Science and Technology, New Delhi.

GOI 2011a. Report on the Working Group on Development and Management of Fisheries and Aquaculture for the XII Five Year Plan (2012-17), Planning Commission, Govt. of India.

GOI 2011b. Report of the Working Group on Skill Development and Training for XII Five Year Plan (2012-2017). Ministry of Labour and Employment, Government of India.

IAMR 2001, Assessment of National manpower needs in agriculture and allied sector, Institute of Applied Manpower Research (IAMR), New Delhi.

IASRI 2011. Agricultural research data year book 2009. Indian Agricultural Statistics Research Institute (IASRI), New Delhi. http://www.iasri.res.in/agridata/11data/ home_11.html.

James, P. S. B. R. 1987. Manpower requirement in mariculture. Proceedings of the symposium on management of coastal aquaculture and oceanic resources of Andamans, Central Marine Fisheries Research Institute, Cochin, p. 55-59. http://eprints.cmfri.org.in/7588/ (Accessed 4 December, 2011).

Kohli, M. P. S. 1998. Manpower requirements in Indian fisheries sector. Fishing Chimes, 18(2): 42-46.

Luv Jasuja and Prashant Kashyap. 2008. Vocational education in India: key challenges and new directions. Technopak Perspective, vol. 03, Technopak Advisors Pvt. Ltd., Gurgaon, India, 82 pp. http://www.technopak.com/Images/ TPK-perspective-vol3.pdf (Accessed 8 October, 2012).
MANAGE 2011. Agri-clinics in India. National Institute of Agriculture Extention Management (MANAGE), Hyderabad (http:www. manage.gov.in)

Munil Sukham. 2010. Human resource need assessment - A look into emerging opportunities. Presented at Aquainvest, 26-28 May 2010, ICAR-Central Institute of Fisheries Education, Mumbai, India.

MPEDA 2011. Marine Products Export Development Authority, Ministry of Commerce and Industry, Govt of India. http://www.mpeda.com/ (Accessed 12 June, 2012).

NFDB 2011. National Fisheries Development Board, Govt of India. http://nfdb.ap.nic.in (Accessed 4 May, 2012).

Parnes, H. S. 1962. Forecasting educational needs for economic and social development, Organisation for Economic Co-operation and Development (OECD), Paris.

Rama Rao, D. and Muralidhar, U. 1994. Agricultural Universities Information System (AGRIUNIS), DST Project Report, National Academy of Agricultural Research Management (NAARM), Hyderabad, 173 pp.

Rama Rao, D., Rashmi Agrawal, Nanda, S. K., Awasthi, I. C., Joshi, G. P., Sanchita Bhattacharya and Indra Kumar. 2011, Assessment of future human capital requirements in agriculture and allied sectors, NAIP Project Report, National Academy of Agricultural Research Management (NAARM), Hyderabad and Institute of Applied Manpower Research (IAMR), New Delhi, 410 pp.

Thakur, N. K., Biradar, R. S. and Sontakki, B. S. 1997. Proceedings of the National Seminar on fisheries education. Central Institute of Fisheries Education, Mumbai, $262 \mathrm{pp}$. 